\title{
The European Union Lawyer as a Common Law Practitioner
}

\section{Manuel Medina Ortega}

(C) ERA 2011

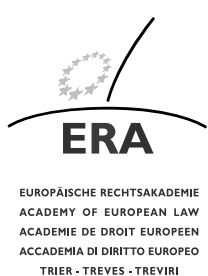

Abstract The author reiterates the concept of "common law" from ancient Roman times and its medieval practice to its modern understanding in England and other common law countries. In his view, European (Union) law represents a similar concept: a legal order that rather looks like patchwork and not like the expression of a unified or systematic legislative approach. EU law is characterised as a system which thanks to the functional approach of European integration will never be complete. It has developed from technical regulations issued by the early Communities as simple "regulatory agencies" into an Area of Law and Justice embracing fundamental rights and values. The author also considers aspects of regulating the legal profession, and training.

Keywords Common law $\cdot$ Roman law $\cdot$ EU law $\cdot$ Soft law $\cdot$ Regulation · Integration · Justice $\cdot$ Human rights $\cdot$ Legal profession $\cdot$ Training

\section{The Law of the Union as Europe's Common Law}

Law is a very old profession in Europe. Legal experts were already giving paid advice to their clients as far back as during the Roman Republic, more than two thousand years ago. Cicero, Gaius, Papinian, Ulpian and Tribonian, are among some of the best known names of practitioners, or "jurisconsultes" as they were called then, in classical Roman times. During the Middle Ages, law was taught at the then nascent universities of Bologna, Pavia, Paris, Oxford or Salamanca. Young men prepared themselves in those early universities in order to become high clerks in the Church, 
well paid civil servants, public notaries or legal counsellors to wealthy merchants. Their curricula included two essential subjects: Latin, the common language of the educated people and of the high administration at that time, and two branches of law, Roman Law and Canon Law.

Roman and Canon Law formed the ius communis or "common law", as opposed to the special laws of the independent cities (the "statutes"), the feudal custom or the law emanating from the royal courts and parliaments of the then nascent modern kingdoms. The 6th century compilation of classical Roman law by the Byzantine Emperor Justinian, the Corpus iuris civilis, had been rediscovered at the end of the 11th century, as a part of the early Renaissance introduced by the new "Holy Roman Empire" of the German kings. In the 12th century, Irnerius and other scholars taught Roman law at the University of Bologna. Roman law was to become the common law of the emerging Holy Roman Empire, ruled by German Emperors with the blessing of the Pope, as opposed to the statutory law of the cities and the territorial laws of the feudal lords. Also in the 12th century in Bologna, a monk named Gratian published the first compilation of the laws of the Church, thus giving rise to a new type of common law, the Canon Law.

The "common law" was taught all over Europe, including England. Later on, the growth of centralised royal power allowed for the development of the absolute monarchies in continental Europe. The only legitimate law in continental Europe was "the king's law". The phrase "common law" became increasingly obsolete in the continent, as all law emanated from the King. The constitutional development of England was an exception. Royal power never became absolute and two competing powers retained their legitimacy to give laws, the King and the Parliament. The phrase "common law" has survived in the British Isles and the English-speaking countries to designate the general or customary law. The survival of this peculiar medieval system of a "general law" opposed to a "statutory law" has caused that the English speaking countries are generally known as the "Common law countries". Within the Englishspeaking countries themselves, the expression doesn't have such a broad meaning. Pollock and Maitland described the development of the historical meaning of the phrase in England as follows:

“A century later, in Edward I.'s days, we frequently find it, though lex communis (commune lei), has by this time become the more usual phrase. The common law can then be contrasted with statute law; still more often it is contrasted with Royal Prerogative; it can also be contrasted with local custom: in short it may be contrasted with whatever is particular, extraordinary, special, with 'specialty' (aliquid special, especialté)."1

Whatever the phrase "common law" means in present day English, it does not refer any longer to the common legal system of the European Middle Ages. In Spain, the phrase "derecho civil común" refers to the common civil law of the realm, as opposed to the special systems of law still applicable in some of the regions, the so-called "derechos forales": Aragón, the Balearic Islands, the Basque Country, Catalonia, Galicia, Navarra and Valencia.

${ }^{1}$ Pollock/Maitland [3], p. 177. 
We could argue that Europe is now witnessing a return to its medieval origins with the appearance of a new ius commune, the law of the European Union. Article 288 of the Treaty on the Functioning of the European Union provides that the Union regulations are binding in their entirety and directly applicable in all Member States, while Union directives are binding as to the result to be achieved, upon each Member States to which they are addressed, but shall leave to the national authorities the choice of form and methods. The European Union law is applicable to relations between the Member States, between the common institutions, between the Member States and the institutions, but also to relations between private parties and between private parties and the Member States or the common institutions. The European Court of Justice, with its seat in Luxembourg, has jurisdiction in a series of cases brought before it in accordance with the rules established in the Treaties. On the other hand, national courts of justice are also competent to enforce the European Union law, with the proviso that in case of doubt about the interpretation of a particular legal rule, the national courts may ask for a preliminary ruling on the subject by the European Court, and, under some circumstances, they may be under an obligation to request such a ruling. Taking into account that a number of European and national administrative offices and independent agencies are responsible for the enforcement of European Union law, we can safely say that a new body of common law is now open to the lawyers willing to practise their skills at a supranational level. For the first time since the Middle Ages, lawyers may practise in a field of law which is now common to many nations. In fact, there has appeared a new breed of lawyers specialised in the regulations, the directives and other instruments of the European institutions. Lawyers specialising in European Union law are, therefore, "common law practitioners", where the phrase "common law" has a new meaning, somewhat similar to the medieval meaning of ius commune.

\section{The Subtleties of European Union Law}

European law is different from the national laws of the Member States in many respects. The national laws of each Member State constitute a comprehensive, unified system. Every situation is supposed to be covered by the national legal system. European Union law, on the other hand, is like a quilt or a patchwork made up of different elements, without an inner unit. It only covers the areas that the Member States have chosen to transfer to the common institutions in accordance with the principle of conferral of rights. Under this principle, "the Union shall act only within the limits of the competences transferred upon it by the Member States in the Treaties to attain the objectives set out therein", so that "competences not conferred upon the Union remain with the Member States" (Articles 5-2 and 4-1 of the Treaty on European Union). Furthermore, the use of the competences so conferred is governed by two principles that introduce further limitations to the law-making powers of the European institutions, the principles of subsidiarity and proportionality (Article 5-1 TEU). "Under the principle of subsidiarity, in areas which do not fall within its exclusive competence, the Union shall act only and in so far as the objectives of the proposed action cannot be sufficiently achieved by the Member States, either at central level or at regional 
and local level, but can rather, by reason of the scale or effects of the proposed action, be better achieved at the Union level." (Article 5-3 TEU). "Under the principle of proportionality, the content and form of Union action shall not exceed what is necessary to achieve the objectives of the Treaty" (Article 5-3, first paragraph TEU). So, the law practitioner will have to undertake his own research in order to determine whether a particular issue is subject to the European Union law or to the national law of one of the Member States. Sometimes, there are concurrent competences, so that both national law and EU law are applicable to a particular situation. A very thin line separates the two jurisdictions.

Once it has been determined that a particular subject falls within the Union's competence and it is also found that Union regulation is not contrary to the principles of subsidiarity and proportionality, a second set of problems will appear in the context of the specific frame of Union rules applicable to the particular situation. In the national context, lawyers use a simple array of legal texts, usually codified and easy to find in the official State publications. EU statutory law is also published in the "Official Journal" of the Union, but little progress has been achieved so far in the area of codification. Pieces of legislation are found here and there, and the lawyer has to pore over a set of rather incoherent texts in order to determine which one of them is applicable to the situation at hand. Moreover, the case law of the European Court of Justice has grown considerably both in extent and depth. It takes some expertise to determine the significance of a given Court decision for the development of the legal situation. Finally, many instruments which are not "legally binding" under the formal words of the Treaty have been recognised "legal effects" by the case law of the Court of Justice. They are considered to form the so-called "soft law" of the Union. This generates confusion when the national courts try to enforce EU law within their jurisdictions. The national courts may give legal effect to provisions included in a series of documents, like the green and the white papers or the action programmes that are not recognised as binding in European law as interpreted by the European Court of Justice. $^{2}$

The Treaties attempt to avoid problems of "forum shopping" by establishing a simple judicial structure. A network of European courts of justice applying European law across the Union does not exist. National courts are to enforce EU law within their respective jurisdictions. The Court of Justice and the General Court, both with their seat in Luxembourg, have limited competences. Besides the preliminary ruling procedure they are basically competent to settle disputes between the Member States and the institutions. Concerning claims raised by private parties against the institutions, the European courts only have jurisdiction for acts of the Union that are "intended to produce legal effects vis-à-vis third parties" (Article 263 of the Treaty on the Functioning of the European Union) and for disputes relating to compensation for damage provided for in the second and third paragraphs of Article 340 TFEU (Article 268 TFEU). The General Court and the Court of Justice are also competent to hear appeals on personnel matters and on the decisions of the Alicante Office on Trade-marks and Designs. Of highest practical relevance is the competence of the Court of Justice to pronounce "preliminary rulings" on the interpretation of EU law

${ }^{2}$ Cf. Senden [4]. See also Heusel [1]. 
at the request of national courts (Article 267 TFEU). This can mean big delays in the taking of decisions by national courts when dealing with EU law, as procedures in the national court are frozen until the European Court has issued its preliminary ruling. The European Court of Justice is not famous for the speed of its procedures.

\section{The Never-Ending Expansion of European Union Law}

The "functional approach" to the integration of Europe proposed by Jean Monnet and adopted by Robert Schuman and the European Communities in the 1950s led to a "step by step" development of the integration process. The political scientists developed the theory of the "spill-over" effect: each particular measure adopted at the European level would generate the need to go ahead with more integration measures. The European integration process is based on long term programming. Integration measures follow one upon each other in a process of mutual reinforcement of decision-making. The Customs Union was the first step in this process, to be followed by the Common Agricultural Policy, tax harmonisation, Monetary Union, a Common Defence and Security Policy, the space of Freedom, Security and Justice, and so on. The European integration process in practice, however, has not followed such a simple, straight forward approach. European initiatives look more like a series of trains leaving the station for different, uncertain destinations which they may or may not reach, through different routes and at different speeds. The European Union has progressed on the basis of a succession of treaties which have been accompanied by a variety of acts adopted by the common institutions. The European Union lawyer has to follow very closely the successive developments in order to foresee what is coming and how to prepare for the changes which are bound to come. A particular crisis may call for urgent measures to prevent unforeseen consequences. It has been said that European integration feeds upon crisis. Thus, after many years of procrastination in the area of financial regulation, the global crisis that began in 2007 led to the adoption of a series of momentous decisions in this area which are changing the shape of the European Union and its decision-making process in this area.

The expansion of the European legal system during the last sixty years has been remarkable. The original Communities were basically regulatory agencies. They aimed to replace national regulations in the economic area with supranational ones, for the purpose of breaking up the existing barriers to the economic activity supported by the national borders. This was the bulk of the regulatory packages of the early Communities: customs, agricultural policy, harmonisation of indirect taxation and so on. The Treaty provisions on competition led to the adoption of rules on company law. At the same time, the setting up of the common market led to measures on the free movement of workers and the freedom of establishment, which in turn led to the development of a common social law and a common commercial law. The consolidation of the institutional structures of the Union opened the door to a constitutional law on integration based upon the rule of law and the recognition of fundamental rights. Here, the Court of Justice played a leading role. The relevance of foreign trade for the European Communities brought about the adoption of rules on international agreements with foreign partners, including assistance to the less developed countries, thus 
moving into the area of public international law. The need to harmonise the internal rules on commercial transactions led to the adoption of rules on trade-marks and industrial design.

Harmonisation of private law has proved to be quite intractable. Member States have asserted the national character of this area of law as an essential element of their sovereignty. Conferral of powers by the States to the Union is strictly limited by the Treaties, as we have seen. The common institutions may only adopt rules when they are required to do so for the completion of the internal market and to achieve other objectives clearly stated in the Treaties. From the very beginning it became clear that the Union could not adopt substantive rules in the area of private law. Member States would have to sign new international agreements among themselves in order to have judicial decisions acknowledged across the internal borders of the Union. Later on, it was decided that the Union could adopt binding acts in this domain, but not of a substantive nature, only procedural. This is how several regulations and directives have been adopted in areas such as the recognition of judicial decisions, co-operation between national jurisdictions on matters of evidence, and the law applicable to situations of a transnational character. Thus, a whole set of rules of private international and judicial co-operation in civil matters has developed within the Union. Finally, the need to fight international terrorism and other forms of international crimes, such as kidnapping and the traffic of persons, tax evasion, the possession of explosives and other instruments on combatting criminal acts across the national borders has led to the development of an important set of EU rules in the field of criminal law.

EU law has thus expanded to encompass practically all areas of law, but under the provision that national rules are applicable unless powers have been expressly conferred to the common institutions. Thus, the European practitioner has to make sure that he understands how the two legal orders, the national and the supranational, interact. Above all, taking into account the fact that the European legal order is continuously expanding and that it now affects the private lives of European citizens, legal developments within the Union must be followed with great attention on a permanent basis.

\section{An Area of Freedom, Security and Justice}

One of the aims of the European Union is the establishment of "an area of freedom, security and justice without internal frontiers, in which the free movement of persons is ensured in conjunction with appropriate measures with respect to external border control, asylum, immigration and the prevention and combating of crime" (Article 3-2 TEU and recital 12 of the Preamble). The achievement of an area of freedom, security and justice is a very ambitious project. It encompasses policies on border checks, asylum and immigration, judicial cooperation in civil and criminal matters and police cooperation (TFEU Part III, Title V, Articles 67ff.). Article 671 TFEU provides that the area of freedom, security and justice shall be constituted "with respect for fundamental rights and the different legal systems and traditions of the Member States". 
Article 6 TEU provides that "the Union recognises the rights, freedoms and principles set out in the Charter of Fundamental Rights of the European Union of 7 December 2000, as adopted at Strasbourg on 12 December, which shall have the same value as the Treaties". This Article raises the Charter of Rights to the level of the Bill of Rights attached to the Constitution of the United States and other similar declarations of the Member States included within the formal written text of their constitutions or contained in a separate document, such as the French universal declaration of human rights or the various documents on human rights which form the backbone of the unwritten British Constitution. The EU Treaty gives practitioners standing to invoke the provisions of the Charter not only before the European Court of Justice but also in purely domestic legal proceedings. The provisions of the Charter may be alleged directly in a national court when one of the rights stated in the Charter is not recognised by the laws of that jurisdiction in the Constitution of one of the Member States. Declaration No. 1 of the Member States annexed to the Final Act of the Lisbon Intergovernmental Conference that approved the new Treaties attempts to limit the effect of Article 6 TEU on the internal law of the Member States by adding the phrase "as they result from the constitutional traditions common to the Member States". The Declaration, however, is only "soft law", as opposed to the binding nature of the text contained in the Treaty, which gives full binding effect to the rights contained in the Charter.

Title VII of the Charter deals with "Justice". It recognises in a formal way the right to an effective remedy and to a fair trial, the presumption of innocence and the right of defence, the principles of legality and proportionality in case of criminal offences and penalties, and the right not to be tried or punished twice in criminal proceedings for the same criminal offence.

The provisions of the Treaty of Lisbon concerning the area of freedom, security and justice are quite ambitious. In some domains, like border checks, asylum and immigration, a great deal of progress has been achieved in the last few years as a consequence of the pressure felt by the population due to the massive arrival of illegal immigrants to the territory of the Member States. Police cooperation has also been strengthened due to the concerns about the terrorist threat and the increase of criminality. Judicial cooperation in civil and criminal matters faces many obstacles due to the incongruities between the different national legal systems, but some progress has also been attained here. The Treaties do not foresee the harmonisation of the basic substantive law, but only an "approximation" in order to establish and consolidate the internal market (Article 114-1 TFEU). This makes it very difficult to consolidate a common civil or criminal law for Europe.

The first attempts to achieve the harmonisation of the laws of the Member States were made through international treaties. However, the treaty-making process is too long and heavy due to the fact that international agreements must be ratified by each Member State. This approach had to be abandoned as it was too cumbersome. The 1992 Treaty of Maastricht foresaw the development of judicial cooperation in civil and criminal matters, through a "third pillar of the Union" based on inter-governmental cooperation. The 1997 Treaty of Amsterdam moved a step further ahead by announcing the ambitious goal of setting up a common space of freedom, security and justice and including some provisions on judicial cooperation in civil and 
criminal matters within the "first pillar", that is the European Community provisions. The European Councils of Vienna in 1998 and Tampere in 1999 announced measures to develop the space of freedom, security and justice. The European Council of 5 November 2004 adopted the Hague Programme for strengthening freedom, security and justice in the European Union, that contained provisions for cooperation in civil and criminal matters including the approximation of the national legal systems in areas such as procedural law, substantive criminal law, and mutual recognition of judicial decisions and public documents. The European Council of 2 December 2009 adopted the "Stockholm Programme on an open and secure Europe serving and protecting the citizens" for the period 2010-2014. An Action Plan to implement the Stockholm Programme was submitted by the Commission on 24 April 2010. ${ }^{3}$ Basically, the approximation of procedural and substantive law, both in civil and criminal matters, is now done through European Union instruments, that is, regulations and directives, which are applicable inside the Member States without the need to go through the already mentioned cumbersome process of ratification of international treaties.

\section{Training in European Union Law}

The relevance acquired by EU law makes it imperative that legal practitioners get proper training in the field. Training in law schools is subject to curricular limitations. The complex details of European law cannot be covered by a regular programme at the law schools in competition with other areas of the law that are essential to the practice of law under any circumstances, such as civil law, criminal law or administrative law. Within a normal undergraduate curriculum, the teacher of European law could hardly go beyond the basic teaching of the institutional framework and the general principles of EU law. Detailed knowledge of particular institutions or fields of EU law can only be acquired at the post-graduate level, in specialised schools such as the Academy of European Law at Trier, Germany, to which Mr. Toulmin has dedicated a lot of his time.

EU law is "law". Facts have to be proved by evidence. Law must be known by the judge even if the parties do not invoke the right legal provisions. The legal practitioner may allege a particular European law provision while pleading before a court of justice, national or European, but it is up to the judge to decide which rule is applicable to the case. This means that judges, including the national judges, are bound to know European law, and this is not an easy task. If national judges are supposed to fulfil their duties properly, part of the judicial training should from now on include training in European law.

The Stockholm Programme and the Action Plan have stressed the importance of training in European law. Thus, the Stockholm Programme foresees the establishment

\footnotetext{
${ }^{3}$ Communication from the Commission to the European Parliament, the Council, the European Economic and Social Committee and the Committee of the Regions. Delivering and Area of Freedom, Security and Justice for Europe's Citizens. Action Plan Implementing the Stockholm Programme. COM(2010) 171 final, 20 April 2010.
} 
of a "systematic European Training Scheme" in which "a substantive number of professionals" should have participated by 2015, or an exchange with another Member State "which might be part of training schemes that are already in place". Although the main target group of the European training schemes are judges, prosecutors, judicial staff and the police, other professionals involved in European cooperation could also be offered European trainings schemes. A preference is stated for already existing training institutions (point 1.2.6, "Training”).

\section{The Regulation of the Legal Profession Within the European Union}

At the present stage of its development, the European Union is a set of regulatory agencies located at a supranational level. National regulations are being superseded by supranational legislation. One of the areas where this is taking place is in the field of the professional services which are now extensively regulated by the Union. The legal profession is no exception in this respect.

The legal profession is covered by the provisions of the Treaties concerning the free movement of persons and services (Article 26-2 TFEU) and the rules on the freedom of establishment of self-employed persons (Article 49 TFEU). The "activities of the professions" are regulated under the heading of the provisions concerning the freedom to provide services (Articles 56 ss.). Lawyers are also affected by the European rules designed to fight discrimination which preclude the existence of barriers based on nationality (Article 18 TEU).

From 1977 on, the European institutions have adopted measures to get rid of obstacles to legal practice within the Union. ${ }^{4}$ A 1989 Directive provided for the general recognition of diplomas, including those required to practise law. ${ }^{5}$ A 1998 Directive regulated the right of establishment of legal practitioners. ${ }^{6}$ These few legal rules were strengthened by the Court of Justice, which has tried by all means to unblock restrictions imposed by national legislation and by professional organisations to the free practice of non-nationals. $^{7}$

A matter of concern for lawyers has been the limitation of their privileges in their relations with their clients as a consequence of the adoption of EU rules addressed to fight money laundering. The European Court of Justice has tried to achieve a delicate balance between the required privileges of the lawyers in their communications with their clients and the need to control the activities of corporations supported by their

\footnotetext{
${ }^{4}$ Council Directive 77/249/EEC of 22 March 1977 to facilitate the effective exercise by lawyers of freedom to provide services, OJ L 78 of 26 March 1977, p. 17.

${ }^{5}$ Council Directive (89/48/EEC) of 21 December 1988 on a general system for the recognition of higher education diplomas awarded on completion of professional education and training of at least three years' duration, OJ L 19 of 23 January 1989, p. 16.

${ }^{6}$ Directive 98/5/EC of the European Parliament and of the Council of 16 February 1998 to facilitate practice of the profession of lawyer on a permanent basis in a Member State other than that in which the qualification was obtained, OJ L 77 of 14 March 1998, p. 36.
}

${ }^{7}$ Cf. Nascimbene/Bergamini [2]. 
lawyers, which might be infringing European rules necessary to preserve security and fight tax evasion. ${ }^{8}$

The legal profession nowadays is so closely identified with the national State that the freedoms provided by the Treaties and strengthened by the case law of the Court of Justice have not really affected the linkage between the national structures and legal practice. Most practitioners keep inside their national jurisdiction and do not attempt to compete outside their national borders. Only a few lawyers working for powerful organisations move around over the frontiers of the nation-State. Even inside the Member States lawyers tend to rather stick to a local clientele and plead before local courts with which they are better acquainted than to move away from their original environment. Legal assistance, where provided, is usually limited to persons living within a national jurisdiction and only involves pleading before national courts. This means that people with low income can hardly afford to sue abroad.

The aims of free movement, freedom of establishment and freedom to provide services have not yet been achieved. Legal practice is still to a large extent a national concern. Attempts to unblock this situation have been carried out in the area of consumer protection, especially through alternative methods of dispute resolution that will not force the aggrieved consumer to go through a great deal of expenditure in order to claim his legitimate rights before a court of justice. Class actions should also be very useful in this respect, but there is a concern in Europe not to follow the American model that encourages litigation which is not really necessary. European-wide legal assistance provided by the European Union is not in sight due to the present dire economic situation of the administrations all through Europe and the need to limit the European Union budget to an absolute minimum.

\section{Conclusions}

Although the Union has gone a long way to harmonise the European legal systems, we are still living with 27 independent national legal orders. For the time being, the EU legal system is only the sketch of a truly united system of rules. EU law covers only small aspects of social relations. Most transactions within Europe are conducted under national law rules even when they refer to transnational situations. In consequence, legal practice within the Union is largely national practice. Lawyers specialised in EU law find themselves constrained by the predominance of domestic concerns and the absence of a European overall perspective. In any case, training in European law is important for lawyers, as well as for judges and civil servants, as they will have to enforce the laws of the Union. Assistance for consumer litigation and for low income claimants should also be considered whenever the improvement of the economic situation will give some breathing space to the resources of the European Union.

\footnotetext{
${ }^{8} \mathrm{Cf}$. the following decisions: Case 155/79 Australian Mining and Smelting Europe Ltd. v. Commission ECR 1982, 1575; Case C-550/07P Akzo Nobel Chemicals and Akcros Chemicals v. Commission, judgment of 14 September 2010, not yet reported.
} 


\section{References}

1. Heusel, W.: "Weiches" Völkerrecht. Eine vergleichende Untersuchung typischer Erscheinungsformen. Nomos Verlagsgesellschaft, Baden-Baden (1991)

2. Nascimbene, B. (The collaboration of Bergamini, E.): The Legal Profession in the European Union. Wolters Kluwer, Austin (2009)

3. Pollock, F., Maitland, F.W.: The History of English Law Before the Time of Edward I, 2nd edn. Cambridge University Press, Cambridge (1968). Revisited with an introduction and select bibliography by S.F.C. Milsom

4. Senden, L.: Soft Law in European Community Law. Hart Publishing, Oxford (2004) 